on the glacial theory in his various writings on glaciers, is in marked contrast to the ignorance of the true state of the case usually displayed by English authors, who ascribe to Forbes the sole credit of all recent progress in the glacial theory.

Forbes's work commenced in 18.4 ; it was in that year that he made his memorable visit to the Glacier of the Aar, and thste found Agassiz, who had at that time already spent five summers in the study of glaciers, and published in 18.40 the preliminary part of the investigations carried on by himself and his companions ("Etudes sur les Glaciers").

Agassiz with his usual freedom in dealing with his associates, which has so often made him appear as following the lead of his pupils, freely imparted to Foroes all he had seen, and certainly had no idea that the hospitality so freely proffered would be returned by the proceedings of Forbts, who appropriated what he could, and misrepresented the nature of his intercourss with Agassiz while his guest on the Glacier of the Aar.

To Tyndall we owe a thorough sifting of the claims of each investigator on the subject, and however unpalatable it may be to national prejudices that the name of Forbes should play a secondary part in these investigations by the side of those of Venetz and Charpentier, Rendu and Agassiz, the fact remains the same, and every fair-minded investigator will thank Tyndall for what he has done.

Cambridge, Mass., April 15

\section{Scientific Endowments and Bequests}

IN the article on scientific endowments and bequests in NATURE for April 24, there is a statement, in reference to the Trinity Natural Science Fellowship, which perhaps requires a little correction.

Although there can be no doubt that the proposed new scheme for the selection of a fellow is in every way better than the old system of selection by routine examination, it is hardly right to speak of the election of a Natural Science Fellow, which took place in October i $\$ 70$, as an "unsuccessful experiment."

It is certainly much to be regretted that circumstances have prevented the gentleman then chosen from strengthening the staff of scientific workers and teachers at Cambridge ; but it is equally certain, that no system of selection that could possibly be desired, would have resulted in the election of a man possessed at once of more promising scientific abilities, and of a more genuine love for science.

The writer of the article seems to think that the examiners on that occasion were in search of what he is pleased to call a "genuine zoologist ;" there is no doubt that there was then as there is now, a striking absence of young men of ability, devoting themselves to zoology; but though the college had announced a preference for a physiologist, yet the examiners were em. powered to recommend either a zoologist, or one following any other branch of natural science.

Trinity College, Cambridge, April 20

\section{Permanent and Temporary Variation of Colour} in Fish

ONE or two episodes in the annals of the Bright on Aquarium for the week just ended deserve a passing note.

Among the Plaice, Plewronceles platissa, added to the general collection, is one remarkable example, having the posterior half of its under surface, usually white, croluured and spotted as brilliantly as the upper one; the line of demarcation between these two colours again, though sinuous, is most abrupt, there being no shading through from one to the other as might have been anticipated. This specimen may be turned to good account by advocates of the Darwinian theory, as affording a remarkable instance of the occasional tendency of a specially modified type to revert to its primeval state-the Pleuro. nectidæ being derived from ancestors originally possessing bilateral symmetry, and an equal degree of coloration on each side.

As the spawning season advances, many of the fish, and more especially certain of the Acanthopterygian order, undergo various important modifications in both their habits and appearance. During the last week or so, many of the larger examples of the Black Bream, or Old Wife (Cantharus lineatus), exhibited in tank 4 on the north side of the Western corridor, have afforded a striking illustration of these phenomena. Hitherto their prevailing tint has been a delicate silvery blue, varied by irregular longitudinal lines of pale yellow, a hue scarcely in harmony with the name by which they are most popularly known. These light colours have now disappeared, or rather become absorbed, in a prevailing shade of deep leaden black, which, while deepest on the back, spreads itself over the whole surface of the fish with the exception of a few transverse lighter bands in the region of the abjomen. The males in particular are most conspicuous for this change, and these retiring from the remainder of the shoal, select certain separate and prescribed areas at the bottom of the tank, where they commence excavating considerable hollows in the sand or shingle, by the rapid and powerful action of the tail and lower portion of their body. A depression of suitable size having been produced, each male now mounts vigilant guard over his respective hollow, and vigorously attacks and drives away any other fish of the same sex that rentures to trespass within the magic circle he has appropriated to himself. Towards his companions of the opposite sex his conduct is far different ; many of the Iatter are now distended with spawn, and these he endeavours by all the means in his power to lure singly to his prepared hollow, now discovered to be a true nest or spawning bed, and there to deposit the myriad ova with which they are laden, which he then protects and guards with the greatest care. Whether the aggregated produce of a large number of females is thus consigned to one bed, and whether the ova are guarded by the male until the young fish make their appearance, are points which, while awaiting confirmation, may be almost confidently inferred, reasoning from the very analogous nest-forming habits of the Gasterostcila or Stickleback fimily, already so familiar to every naturalist. The male of the Lump fish (Cy'lopterus lumpus) is said to watch over the spawn of the female in a very similar manner, and at the particular time of the year, early spring, when it is deposited, assumes the most lively tints of red and blue, which disappear asain after his paternal duties have been discharged, and are not retained through life as has been formerly supposed. On this point we have direct evidence from specimens confined within the aquarium walls. For yet. another instance of change of co'our in the male fish, associated with its nest-forming habit; in the same Acanthopterygian order, I am indebted to a recent visit to the aquarium at the Crystal Palace, where Mr. Loyd directed my attention to a male example of the Cuckoo IVrasse (Labrus mixtus), which had formed a deep hollow in the sund of its tank, and was endeavouring in the most persuasive manner to induce a female of the same species to share it with him, swim. ming backwards and forwards between her and the completed nest, and plainly exhibiting the greatest anxiety for her to follow. The normal brilliancy of this fish was supple nented by a light opaque patch that extended over a considarable portion of the back of his head and shoulders, while the tints of the remaining portion of the body were more than ordinarily deepened.

\section{VV. SAVILLE KENT}

\section{On Approach caused by Velocity and Resulting in Vibration}

Prof. J. Clerk-Maxivell, in his recent papar on "Action at a Distance," has brought under notice again the experiment; of Prof. Guthrie "On Approach caused by Vibration," and has so well summarised in popular language the facts investigated and the conclusions arrived at, that fitting opportunity appears to present itself to me for calling the attention of the scientific world to phenomena closely allied to those under review although more complex in their manifestation, since in these velocity is in dependent of, yet initiates vibration. That they have not been referred to in the experiments either by Prof. Guthrie, Challis, and others who have taken part in the discussion is probably to be accounted for in the unfortunate although convenient habit indulged in by experimentalists of using the tuaing fork as the agent for demonstration.

The fo!lowing passage from Prof. J. Clerk-Maxwell's paper allude 1 to will best introduce my own observations- " Here is a kind of attraction with which Prof. Guthrie made us faniliar. $A$ disc is set in vibration and is then brought near a light suspended body which immediately begins to move towards the disc as if drawn towards it by an invisible cord. What is this cord? Sir W. Thomson has pointed out, that in a moving fluid the pressure is least where the velocity is greatest. The velocity of the vibratory motion of the air is greatest near the disc Hence the pressure of the air on the suspended body is less on the side nearest the disc than on the opposite side; the body yields to the greater pressure and moves towards the disc. The 